\title{
National Revenue Administration \\ - current organisational and financial problems
}

\section{Krajowa Administracja Skarbowa - aktualne problemy organizacyjno-finansowe}

\begin{abstract}
The article is devoted to current problems related to the functioning of the National Tax Administration, at the same time relating to the ratio legis of that institution, but also regarding the education of its employees and officers of the Customs and Revenue Service. The Author of the article formulated in this respect both de lege lata and de lege ferenda postulates, using for this purpose, among others empirical material derived from information obtained from the Minister of Finance, the Head of the National Revenue Administration, the Director of the Bureau of the Domestic Fiscal Information, Directors of a Fiscal Administration Chambers, but also from parliamentary interpellations.
\end{abstract}

Keywords: tax administration (revenue administration); tax proceedings; National Revenue Administration; employee; officer; higher education. 
Streszczenie. Artykuł poświęcony jest aktualnym problemom związanym z funkcjonowaniem Krajowej Administracji Skarbowej, zarazem odnoszącym się do ratio legis tejże instytucji, ale także dotyczącym wykształcenia jej pracowników oraz funkcjonariuszy Służby Celno-Skarbowej. Autor publikacji sformułował w tym zakresie postulaty zarówno de lege lata, jak i de lege ferenda, wykorzystując w tym celu m.in. materiał empiryczny pochodzący z informacji uzyskanych od Ministra Finansów, Szefa Krajowej Administracji Skarbowej, Dyrektora Krajowej Informacji Skarbowej, Dyrektorów Izb Administracji Skarbowej, ale także $\mathrm{z}$ interpelacji poselskich.

Słowa kluczowe: administracja podatkowa (skarbowa); postępowanie podatkowe; Krajowa Administracja Skarbowa; pracownik; funkcjonariusz; wyższe wykształcenie.

\section{Introduction}

On 1 March 2017, the National Revenue Administration (NRA, Krajowa Administracja Skarbowa) started to operate in Polish legal system ${ }^{1}$. This merged the tax administration, customs service, and tax control into a single "formation"2. The nearly 3-year period of activity of the National Revenue Administration, seem as good justification for analysing its basic problems together with attempting to determine the ratio legis of introduced legal regulations. However, in order to properly deal with the above mentioned research problem, the legal status of the National Treasury Administration as a specialized government administration should first be correctly "decoded" in comparison with the assumptions made by the legislators when instituting it. To this end, the subject of research has been enriched with information obtained from the Minister of Finance, Investment and, Development, the Head of the National Treasury Administra-

1 Act of 16 November 2016 on National Revenue Administration (consolidated text, Dz.U. [Polish Journal of Laws] of 2019 poz. [item] 768 with subsequent amendments), hereinafter: A.N.R.A.

2 More broadly I. Nowak, M. Dominiak, Krajowa Administracja Skarbowa a uszczelnianie systemu podatkowego - spostrzeżenia po dwóch latach funkcjonowania [in:] P. Łabuz, I. Malinowska, M. Michalski (ed.), Przestępczość gospodarczoekonomiczna - przeciwdziałanie i zwalczanie, Warszawa 2020. 
tion, the Director of National Treasury Information, and the Directors of Fiscal Administration Chambers. Although the framework of the study did not allow for an exhaustive presentation of the theoretical and legal controversies related to the subject under consideration, the considerations discussed have another important meaning - they are another voice directed to the supposedly rational legislator to create a target model of the tax system without permanent legislative changes in this respect together with an efficiently functioning tax (treasury) administration ${ }^{3}$.

\section{National Revenue Administration as a specialized government administration}

The National Revenue Administration is a specialized government administration performing tasks within the scope of the realization of income from taxes, customs duties, fees and non-tax budget receivables, the protection of the interests of the State Treasury, and protection of the customs territory of the European Union, as well as providing service and support for the taxpayer (entrepreneur) and other entities in the proper performance of tax and customs duties ${ }^{4}$. The purpose of enacting the Act on the National Revenue Administration - as stated in the preamble (the socalled solemn introduction) ${ }^{5}$ to this legal act - was based on the recognition of the importance of the constitutional obligation to bear public burdens and benefits, in particular taxes and customs duties, concern for the

3 B. Brzeziński, W. Nykiel, Legislacja podatkowa [in:] B. Brzeziński (ed.), Prawo podatkowe. Teoria. Instytucje. Funkcjonowanie, Toruń 2009, p. 148; B. Brzeziński, W. Nykiel, Stan prawa podatkowego w Polsce. Raport 2010, „Kwartalnik Prawa Podatkowego" 2011, No 1 p. 61 et seq.

4 See Article 1(2) of A.N.R.A.; L. Bielecki, A. Gorgol (eds), Ustawa o Krajowej Administracji Skarbowej. Komentarz, Warszawa 2018; A. Melezini, K. Teszner (eds), Krajowa Administracja Skarbowa. Komentarz, Warszawa 2018; K. Różycki, A. BielskaBrodziak, Właściwość rzeczowa organów podatkowych, Lex/el.

5 The preamble is "applied" when the legislator wants to define the objectives of a given legal regulation expressis verbis and to explain the "spirit" of the legal act issued cf. the judgment of the Voivodeship Administrative Court in Opole of 5 February 2004, II SA/Wr 318/01, CBOSA; W. Skrzydło, Konstytucja Rzeczypospolitej Polskiej. Komentarz 2013, Lex/el; B. Banaszak, Konstytucja Rzeczypospolitej Polskiej. Komentarz 2012, Legalis/el. 
financial security of the Republic of Poland, and protection of the security of the customs territory of the European Union, in order to ensure modern and friendly execution of tax and customs obligations, as well as effective collection of public levies.

The National Revenue Administration has been in operation since 1 March 2017 on the basis of the Act of 16 November 2016 on National Revenue Administration and the Act of 16 November 2016 introducing the Act on National Revenue Administration ${ }^{6}$. The National Revenue Administration was established by way of consolidation of the tax administration, customs service and fiscal control, which included 16 tax chambers, 16 customs chambers, 16 fiscal control offices, 400 tax offices, 45 customs offices, and 143 customs branches. This resulted in the establishment of the National Revenue Administration with its structure ${ }^{7}$ including:

a) 16 fiscal administration chambers ${ }^{8}$, which were established by way of a combination of "service processes" originally implemented in revenue chambers, customs chambers and fiscal control offices;

b) 16 customs and treasury offices integrating the control tasks previously carried out by the fiscal control and customs offices;

c) 400 tax offices $^{9}$ (including 20 specialized departments for key taxpayers $)^{10}$.

6 Act of 16 November 2016 introducing the Act on National Revenue Administration (Dz.U. of 2016, poz. 1948 with subsequent amendments); more broadly K. Teszner, M. Wincenciak, P. Pietrasz, Nowe tendencje $w$ procedurach kontrolnych na przykładzie kontroli celno-skarbowej [in:] J. Jagielski, M. Wierzbowski (eds), Prawo administracyjne dziś i jutro 2018, Lex/el.

7 The bodies of the National Revenue Administration are: the minister competent for public finance; the Head of the National Revenue Administration; the Director of the National Revenue Information; the Director of the Chamber of Revenue Administration; the Head of the tax office; the Head of the customs and treasury office - Article 11 ( 1) of the A.N.R.A. Accordingly, the organizational units of the National Revenue Administration are: organizational units of the office serving the Minister; National Revenue Information; chambers of revenue administration; revenue offices; customs and treasury offices together with subordinate customs branches; School - Article 36(1) of A.N.R.A.

8 Corresponding to the number of provinces.

9 Here without changes compared to the previous organisational structure. 
As of 15 June 2018, the number of persons employed and serving in the National Revenue Administration ${ }^{11}$ amounted to $60787^{12}$, of whom:

a) persons aged 18-35 amounted to 10874 (17.89\%);

b) persons aged 36-45-19187 (31.56\%);

c) persons aged 46-55 - 19795 (32.56\%);

d) persons aged 56-65 - 10824 (17.81\%);

e) persons aged 65 and more $-107(0.18 \%)^{13}$.

As of 5 March 2019, 40613 women and 21022 men were employed in organizational units of the National Revenue Administration ${ }^{14}$, and their share by categories of offices is $75.5 \%$ to $24.5 \%{ }^{15}$. It should also be noted that in 2018, 9 chaplains served in the National Revenue Administration, whose pastoral activity is regulated by an agreement between the

10 I. Nowak, M. Dominiak, Krajowa..., pp. 112-113; the letter of the Minister of Development and Finance of 7 February 2017, RS6.054.3.2017, http://orka2.sejm.gov.pl/ INT8.nsf/klucz/658C47EE/\%24FILE/i09407-o1.pdf, (access on-line: 25.09.2019); the letter of the Minister of Finance of 23 April 2018, DOW6.054.8.2018.KZM, http://orka2.sejm.gov.pl/INT8.nsf/klucz/658C47F2/\%24FILE/i20954-o1.pdf (access on-line: 25.10.2019); L. Bielecki, Ustrojowe prawo administracyjne (podatkowe) dotyczqce Krajowej Administracji Skarbowej jako przykład wpływu ideologii politycznej na kształt prawa, „Przegląd Prawa Publicznego” 2017, No 7-8, p. 44 et seq.

11 Within the framework of the National Revenue Administration, the Customs and Fiscal Service is established, which is a homogenous and uniformed formation formed exclusively by its officers. As of 31 December 2018, 10511 officers served in the Customs and Fiscal Service - the letter of the Minister of Finance of January 2019, DLK2.054.2.2019, http://orka2.sejm.gov.pl/INT8.nsf/klucz/ATTB93DPC/\%24FILE/ i28824-o1.pdf. (access on-line: 20.09.2019).

12 Excluding persons on unpaid and parental leave exceeding 1 month.

13 The letter of the Minister of Finance of 9 July 2018, BDG7.054.20.2018, http://www.sejm.gov.pl/Sejm8.nsf/InterpelacjaTresc.xsp?key=01D534FA, (access online: 30.09.2019).

14 See the letter of the Minister of Finance of 5 March 2019, BDG7.054.2.2019, http://orka2.sejm.gov.pl/INT8.nsf/klucz/ATTBA2K5J/\%24FILE/i29295-o1.pdf, (access on-line: 20.10.2019).

15 Status as of 31 December 2018 in persons - see employment and turnover in the civil service in 2018, (Annex 1 to the Report of the Head of the Civil Service on the status and performance of the tasks of the civil service in 2018), https://dsc.kprm.gov.pl/ sites/default/files/zal_1_zatrudnienie_w_sluzbie_cywilnej_w_2018_r_0.pdf., (access on-line: 20.10.2019). 
Head of the National Revenue Administration and representatives of churches or religious associations ${ }^{16}$.

The employment level divided into individual Fiscal Administration Chambers in Poland as of 31 August 2019 is as follows ${ }^{17}$ :

1. FAC in Białystok - 1408 employees and 997 officers of the Customs and Fiscal Service;

2. FAC in Bydgoszcz - 2574 employees and 225 officers of the Customs and Fiscal Service;

3. FAC in Gdańsk - 2839 employees and 650 officers of the Customs and Fiscal Service;

4. FAC in Katowice - 5496 employees and 622 officers of the Customs and Fiscal Service;

5. FAC in Kielce - 1246 employees and 132 officers of the Customs and Fiscal Service;

6. FAC in Kraków - 3955 employees and 426 officers of the Customs and Fiscal Service;

7. FAC in Lublin - 2399 employees and 1738 officers of the Customs and Fiscal Service;

8. FAC in Łódź - 3303 employees and 431 officers of the Customs and Fiscal Service;

9. FAC in Olsztyn - 1516 employees and 784 officers of the Customs and Fiscal Service;

10. FAC in Opole - 1413 employees and 199 officers of the Customs and Fiscal Service;

11. FAC in Poznań - 4402 employees and 496 officers of the Customs and Fiscal Service;

12. FAC in Rzeszów - 2175 employees and 1089 officers of the Customs and Fiscal Service;

16 Article 10 of A.N.R.A.; the letter of the Minister of Finance of 17 April 2019, DLK6.413.113.2019, http://orka2.sejm.gov.pl/INT8.nsf/klucz/ATTBBDDBW/\%24FILE/ i30400-o1.pdf., (access on-line: 20.10.2019).

17 The above data do not include persons employed under a replacement contract and persons on unpaid and parental leave - according to the letter of the Minister of Finance, Investment and Development of 14 October 2019, BMI1.0124.1103.2019. 
13. FAC in Szczecin - 2522 employees and 438 officers of the Customs and Fiscal Service;

14. FAC in Warsaw - 6868 employees and 1226 officers of the Customs and Fiscal Service;

15. FAC in Wrocław - 3695 employees and 482 officers of the Customs and Fiscal Service;

16. FAC in Zielona Góra - 1437 employees and 396 officers of the Customs and Fiscal Service.

\section{National Revenue Administration - assumptions versus reality}

In 2018, the National Revenue Administration employed about 39\% of the members of the civil service corps. However, as in other "segments" of the civil service, interest in working in the National Revenue Administration is declining. This is mainly attributable to the low competitiveness of salaries, which differs from the level offered on the labour market. Salaries in the National Revenue Administration - as the Head of the Civil Service notes - are often lower than salaries in popular retail chains ${ }^{18}$. It should be pointed out here that in 2015, basic salaries in tax offices, i.e. in the most numerous group of tax (treasury) administration employees, in half of cases did not exceed PLN 2810.76 gross $^{19}$. It is also worth noting that this problem was noticed by the Minister of Development and Finance, who noted that in tax offices and chambers about $66 \%$ of the total number of employees had remuneration below 3 thousand PLN (gross of course $)^{20}$. The statement by D. Lach (head of the Company's

18 Report of the Head of the Civil Service on the state of the civil service and the performance of its tasks in 2018, https://dsc.kprm.gov.pl/aktualnosci/sprawozdanie-szefasluzby-cywilnej-za-2018-rok (access on-line: 20.10.2019).

19 J. Kulicki, Koncepcja Krajowej Administracji Skarbowej w świetle problemów administracji danin publicznych w Polsce, „Analizy i Studia” 2016, No 2, p. 35; ibid. Administracja danin publicznych w Polsce, Warszawa 2014; K. Teszner, Administracja podatkowa i kontrola skarbowa w Polsce 2012, Lex/el.

20 The letter of the Minister of Development and Finance dated November 2016, RS2.054.13.2016.ZDJ, 
Trade Union Organisation NSZZ “Solidarność” of Tax Administration Employees of the Silesian Voivodeship), who argues that salaries in the tax (treasury) administration in the years 2007-2015 were frozen and not even indexed for inflation should be understood in a similar way. At the same time, jobs were blocked, and no new employees were hired in place of those retiring and those who had resigned themselves ${ }^{21}$. "The number of tasks was increasing, and the number of people decreasing. It has become the norm to work after hours for which the FAC employees are not paid"22. Another "pathology" of the tax (treasury) administration of the last dozen or so years, which effectively demotivated employees (officers), was the appointment of the so-called "acting tax authorities", obviously according to the "proper party line". For example, the data obtained in 2013 by "Dziennik Gazeta Prawna" show that 15 out of 16 directors of tax chambers were acting directors, and some of them had been since 2008. Also 42 tax offices were headed by acting heads $(10 \%)^{23}$. Hence, it is clear that it is political influence in various forms, interfering with the activities of the tax (treasury) administration, which has worsened the rules of functioning of the vast majority of its officials ${ }^{24}$.

The year 2017 marked the highest - not recorded since $2008^{25}$ - "resignation” rate from employment at the National Revenue Administration

http://orka2.sejm.gov.pl/INT8.nsf/klucz/658C47ED/\%24FILE/i07304-o1.pdf. (access on-line: 20.10.2019).

21 http://www.solidarnosc.org.pl/srsp/index.php/57-wzrost-plac-w-administracji-skarbowej, (access on-line: 20.10.2019).

22 Ibidem.

23 G. Leśniak, Administracja skarbowa w rękach osób pełniq̨cych obowiq̨zki. To próba obchodzenia prawa, https://podatki.gazetaprawna.pl/artykuly/680803,administracjaskarbowa-w-rekach-osob-pelniacych-obowiazki-to-proba-obchodzenia-prawa.html (access on-line: 20.10.2019).

24 G. Leśniak, 30 lat urzędów skarbowych w Polsce: Przydałby się szef administracji podatkowej, https://podatki.gazetaprawna.pl/wywiady/677504,30-lat-urzedow-skarbowych -w-polsce-przydalby-sie-szef-administracji-podatkowej.html (access on-line: 25.10.2019); T. Wojciechowski, Urzędnicy skarbowi odchodzq z urzędów. Zamiast karać, pomagaja podatnikom, https://podatki.gazetaprawna.pl/artykuly/663749,urzednicy-skarbowiodchodza-z-urzedow-zamiast-karac-pomagaja-podatnikom.html (access on-line: 24.10.2019).

25 Report of the Head of the Civil Service for 2017, https://dsc.kprm.gov.pl/sprawozdanieszefa-sluzby-cywilnej-za-2017-rok-0. 
of $13.7 \%$. By the way, in 2018, the highest number of overtime hours over 400,000 (approx. 42\% in the entire civil service) - were generated by employees (officers) of the National Revenue Administration. The same was true in 2017 - these were employees and officers of the National Revenue Administration - 348 thousand (39\%) ${ }^{26}$. It is also impossible to ignore the fact that the number of persons in substantive positions dealing with "appeal proceedings" at the end of 2018 in all the Tax Administration Chambers in Poland amounted to 1353, while in the corresponding final period of 2016 there were 1388 employees, while it should be noted that the data as at the end of 2016 do not include employees and cases relating to customs proceedings and proceedings on excise duty and tax on games, for which the Directors of Tax Administration Chambers became competent as of 1 March $2017^{27}$. As a result, the number of cases per year on average to be handled by the substantive employee dealing with "appeal proceedings" at the end of 2018 was 1181.91. At the end of the same period in 2016, it amounted to 866.73 per capita ${ }^{28}$. This leads to the conclusion that the average increase in the workload per one substantive position in the appeal bodies at the end of 2018 was about $36 \%$ as compared to the same period in 2016. Although in the organizational units of the National Revenue Administration, flexible working hours or individual work schedules are in force ${ }^{29}$ - after so many years of neglect (or perhaps rather inaction) - these institutions do not deliver the intended results. Undoubtedly, we are dealing here with a lack of consistency on the part of the legislator. It is only to be hoped that the issue under consideration will be addressed "without undue delay" by adequate statutory regulations.

26 Ibidem.

27 Own study based on the letter of the Minister of Finance of 7 March 2019, DOW6.054.3.2019.KZM, http:/orka2.sejm.gov.pl/INT8.nsf/klucz/ATTBA6EZY/ \$FILE/z08378-o1_1.pdf (access on-line: 28.10.2019).

28 Ibidem.

29 The letter of the Minister of Finance dated 5 March 2019, BDG7.054.2.2019, http://orka2.sejm.gov.pl/INT8.nsf/klucz/ATTBA2K5J/\%24FILE/i29295-o1.pdf (access on-line: 28.10.2019). 
The basic salary offered to persons with higher education ${ }^{30}$ in the National Revenue Administration is by no means encouraging or competitive $^{31}$, given the complex and constantly changing tax system ${ }^{32}$. One would like to be as enthusiastic as the officers serving in the elite unit for special tasks of the National Revenue Administration and say "I don't feel helpless anymore; I enjoy my work; I may have lost in terms of finances, but I am evolving and having fun"33. But is it possible with this salary? Of course, it's not only the salary that determines the work performed. Unfortunately, "the low level of salaries, and thus the lack of proper motivation (...), the lack of a guaranteed path of professional advancement have been causing an outflow of experienced staff to the private sector"34. This negative trend creates significant problems in the organization of the work of the National Revenue Administration. The question then arises - how to counteract it? Even multinational corporations note that "we don't live to work" ${ }^{35}$ (sic!) and in addition to such benefits as "fruity Tuesdays, sweet Wednesdays, beer Fridays, rest hammocks,

30 According to the report "Education at a glance 2019", in 2018 as many as $44 \%$ of "young adults" (25-34) in Poland received higher education. Compared to 2008, this is an increase of $12 \%$ - https://www.prawo.pl/student/wyksztalcenie-polakow-w-2018-rponad-polowa-zdobyla-wyzsze,472295.html.

31 Owing to the fact that a significant percentage of treasury employees, but also some groups of officers, received low remuneration - in the first stage after the creation of the National Revenue Administration - the level of basic remuneration/basic emoluments with an allowance for the service grade was set at a certain minimum level corresponding to the current multiplier of 1.61 (i.e. ca. PLN 3000 gross in 2017) - the letter of the Minister of Finance of December 2018., DLK6.054.5.2018, http://orka2.sejm.gov.pl/INT8.nsf/klucz/ATTB7BJK5/\%24FILE/i27640-o1.pdf (access on-line: 23.10.2019).

32 According to the data as of 25 September 2018, the statistics of remuneration of employees and officers in the National Revenue Administration together with all allowances, according to the median, amount to PLN 4609.65 gross - the letter of the Minister of Finance of 30 January 2019, DLK6.054.2.2019, http://orka2.sejm.gov.pl /INT8.nsf/klucz/ATTB8YE75/\%24FILE/i28585-o1.pdf (access on-line: 23.10.2019).

33 M. Suchodolska, KAS, czyli każda anomalia skasowana, „Dziennik Gazeta Prawna” of 29 April - 5 May 2019, No 83/84/85 (4985/4986/4987) year 25, p. 18.

34 R. Kosińska, E. Ruśkowski, P. Woltanowski, Efektywność służb podatkowych w okresie ich reformowania - wybrane zagadnienia, „Finanse, Rynki Finansowe, Ubezpieczenia” 2016, No 6, pp. 17-27.

35 https://www.prawo.pl/kadry/chief-happiness-officer-happy-manager-czy-wartotworzyc-takie,472842.html (access on-line: 23.10.2019). 
daily breakfasts and lunches at work", introduce the position of so-called "happy managers or chief happiness officers" 36 . Of course, corporate "methods of operation" should not be "transplanted" into the administration of public levies. However, it is reasonable to subject this problem to the consideration of the legislator and, at the same time, of the "decisionmakers" from the Ministry of Finance, so that at some point a similar finding on the grounds of the National Revenue Administration, such as the one made by the Mayor of the Capital City of Warsaw during the socalled failure of the transmission system in the "Czajka" sewage treatment plant, according to whom "it is not so that we have solutions that are ready at this moment, because I remind you that the main pipeline has failed, but also the emergency one has failed. Hence, we have a problem. That is why we are looking for an emergency solution. Today such an emergency solution is not yet available" 37 .

In the context of the above considerations, it is also worth noting that as of 1 March 2017, an official position of a tax adviser was introduced to the National Revenue Administration ${ }^{38}$. However, the purpose of this institution is impossible to "decode" because the legislator is silent in the justification to law introducing this "mysterious" position. Although this problem will be the subject of a separate study, it should be emphasized that the institution of a tax adviser, who exercises the powers of the tax authority to resolve tax matters, is redundant, as it serves only to multiply official positions in public administration ${ }^{39}$. It should only be pointed out, as a side-note, that 89 tax advisers are employed in the organizational

\footnotetext{
Ibidem.

https://www.youtube.com/watch?v=SUeoM_qhE9w (access on-line: 23.10.2019).

8 Pursuant to Article 13(2c) of the Act of 29 August 1997 - Tax Ordinance (consolidated text: Dz.U. of 2019, poz. 900 with subsequent amendments), hereinafter referred to as: TO, in the area of tax matters settlement, the powers of the head of the tax office, the head of the customs and tax office and the director of the tax administration chamber, as the tax authority, are also vested in the tax adviser, who performs judicial activities in this authority. See also I. Nowak, Upoważnienie pracownika do załatwiania spraw w imieniu samorzq̨owego organu podatkowego, „Przegląd Podatków Lokalnych i Finansów Samorządowych” 2017, No 10, pp. 19-27.

39 K. Teszner, Komentarz do art. 13 o.p. [in:] L. Etel (ed.), Ordynacja podatkowa. Komentarz 2019, Lex/el; tenże, Uprawnienia radcy skarbowego w zakresie załatwiania spraw podatkowych, „Procedury Administracyjne i Podatkowe” 2018, No 2, p. 17 et seq.
} 
units of the National Revenue Administration ${ }^{40}$. However, at this point it is worth indicating that the tax adviser is entitled to a court executive's allowance $^{41}$, and its rate is from $10 \%$ to $50 \%$ of the basic salary and may be increased $^{42}$. In practice, the Directors of the Tax Administration Chambers enjoyed and still enjoy full freedom in appointing tax advisers, as no guidelines for their employment have yet been issued by the Minister of Development and Finance ${ }^{43}$. As a result, no competitions for the positions of tax advisers (sic!) have ever been held because - as the Director of the Wrocław Chamber of Tax Administration aptly put it - "legal regulations do not impose any obligation to conduct them"44. For the sake of order, it is worth mentioning that the employees of the Legislative Office of the Senate Chancellery raised various doubts concerning the provision of Article $13 \S 2$ c of the Opinion on the Act, posing, among others, the following questions: why none of the provisions of the Act on National Revenue Administration formulates the principles for appointing and placing such an entity within the structures of the body; whether this provision assumes the obligation to "appoint" a tax adviser in each office serving the body; on whose behalf he or she will issue decisions (in his or her own name, the body's name); how will the "division" of cases resolved by the body and the adviser take place; why a tax adviser, but not an employee authorised under Article 143 of the Opinion on the Act, will be entitled to

40 As of 31 March 2019 - according to the letter of the Minister of Finance dated 23 August 2019., BMI1.0124.926.2019, (access on-line: 23.10.2019). For example, in April 2018, there were 74 tax advisers - according to the letter of the Minister of Finance of 12 October 2018, RM-10-159-18, http://bip.kprm.gov.pl/download/75/40389/ RM-10-159-18.pdf (access on-line: 23.10.2019).

41 The court executive's allowance is not applicable to other employees (officers) employed in other positions - the letter of the Director of the Fiscal Administration Chamber in Kielce of 11 April 2019, 2601-IWK.0150.35.2019.

42 Ordinance of the Minister of Development and Finance of 26 April 2017 on court executive's allowance for the position of tax adviser, Dz.U. of 2017, poz. 863.

43 The letter of the Minister of Development and Finance of 26 April 2017, BMI1.0124.298.2017, http://www.skarbowcy.pl/blaster/extarticle.php?show=article\& article_id=25342 (access on-line: 28.10.2019).

44 The letter of the Director of the Fiscal Administration Chamber in Wrocław of 5 April 2019, 0201-IWK.0150.34.2019. 
a court executive's allowance under the Act on National Revenue Administration $^{45}$.

\section{The educational background of the employees (officers) of the National Revenue Administration in the light of the right to good public administration}

In addition to certainty, tax law requires employees (officers) of (tax) authorities to comply with established normative rules, so that the obligations imposed on citizens result directly from generally applicable legisla$\operatorname{tion}^{46}$. In accordance with the principle of the rule of law, a tax (revenue) administration authority, when issuing a tax ruling, may neither impose an obligation on a citizen, nor refuse to grant him/her entitlement if it does not prove that it is empowered to do so by specific legal provisions, since these are fundamental principles underlying the operation of the public administration apparatus in a State governed by the rule of law ${ }^{47}$. "Since the taxpayer is required to fulfil not only the obligation to support the State, but also to show the utmost diligence as regards the manner of disclosure of the tax liability and the manner of payment" ${ }^{48}$, it is the tax debtor who must be absolutely certain that his/her case will be dealt with by a competent official, in accordance with the principles of legalism. Only such a conviction will enable the party to identify itself with its own state, which they financially support, while assuming mutual loyalty and

45 Opinion on the Act - Provisions introducing the Act on National Revenue Administration (print No 313), Warsaw, 2 November 2016, https://www.senat.gov.pl/download/gfx/ senat/pl/senatekspertyzy/3638/plik/313.pdf (access on-line: 28.10.2019).

46 Judgment of the Voivodeship Administrative Court in Warsaw of 19 November 2008, III SA/Wa 1307/08, CBOSA.

47 Judgment of Supreme Administrative Court of 18 April 2019, I OSK 1750/17, CBOSA; judgment of Supreme Administrative Court of 17 November 1982, II SA 1474/82, CBOSA.

48 A. Gomułowicz, Moralność podatkowa - uwarunkowania i zasadnicze dylematy [in:] A. Gomułowicz, J. Małecki (ed.), Ex iniuria non oritur ius. Księga pamiq̨tkowa ku czci Profesora Wojciecha Łq̨czkowskiego, Poznań 2003, p. 370. 
trust $^{49}$. Thus, a taxpayer who does not have an equal position with an active subject of the tax-legal relationship ${ }^{50}$, "should build his or her sense of legal certainty, not only on the very wording of tax laws" 51 , but also on the conviction that professional employees (officers) of the tax (revenue) administration interpret the rules of tax law correctly.

There is no doubt that the employees (officers) working in the National Revenue Administration should have higher education, but above all, their education should be "targeted" in terms of the assessment, collection, and execution of public-law levies or, more broadly, the functioning of the public finance system. Otherwise, persons “deprived” of a profiled education in cases of e.g. settlement of factual or legal doubts will issue "judgments" to the detriment of the taxpayer (in dubio pro fisco) ${ }^{52}$, and not - as indicated in Article 2 of the Opinion on the Act - in dubio pro tributario ${ }^{53}$, thus violating the principle of inspiring confidence in the tax (revenue) authorities ${ }^{54}$. Similarly, persons without the appropriate qualifications may, when deciding on an individual tax case, use the interpretative guidance of the authorities superior to the authority deciding the

49 T. Dębowska-Romanowska, Zdanie odrębne do wyroku TK z dnia 6 marca 2002 r., P. 7/2000, Legalis/el.

50 Judgment of Voivodeship Administrative Court in Opole of 17 August 2010, II SA/Ol 587/10, CBOSA; judgment of Voivodeship Administrative Court in Opole of 30 November 2009, II SA/Op 277/09, CBOSA.

51 R. Mastalski, Wprowadzenie do prawa podatkowego, Warszawa 1995, p. 100.

52 See I. Nowak, Koszty uzyskania przychodów z praw autorskich przysługujq̨ce nauczycielom akademickim, „Toruński Rocznik Podatkowy” 2017/el, pp. 165-197.

53 Judgment of Voivodeship Administrative Court in Poznań of 9 November 2010, I SA/Po 626/10, CBOSA; judgment of Voivodeship Administrative Court in Kraków of 22 September 2010, I SA/Kr 1738/09, CBOSA; more broadly A. Mariański, Rozstrzyganie wattpliwości na korzyść podatnika. Zasada prawa podatkowego, Warszawa 2009, passim; I. Nowak, Ciężar dowodzenia w postępowaniu podatkowym podstawowe problemy [in:] B. Kucia-Guściora, M. Münnich, A. Zdunek, R. Zieliński (ed.), Stanowienie i stosowanie prawa podatkowego w Polsce. Ocena i kierunki zmian, Lublin 2016, pp. 183-205.

54 More broadly I. Nowak, Terminowość załatwiania spraw przed samorzq̨dowymi organami podatkowymi, „Przegląd Podatków Lokalnych i Finansów Samorządowych” 2017, No 11/12, pp. 18-26/21-28. 
case, in particular the central authorities ${ }^{55}$, when interpreting legal provisions, which will of course constitute a contra legem action ${ }^{56}$.

Taking into account the "poor quality" of legal acts in the field of tax law, including the imprecision of their provisions and continuous amendments, etc. - in the author's opinion - in principle, only fields of study such as: law, administration, tax law and accounting, tax consultancy and, to a limited extent, economics or finance and accounting ${ }^{57}$, will properly prepare their graduates for the correct application and interpretation of substantive and procedural tax law standards. It should be remembered that in addition to the specialist education of the employees (officers) of the National Revenue Administration, the so-called "practical training" of a person even with an appropriate profile of studies contractually lasts 2 years. Therefore, it is hard not to be under the impression that it is mainly due to "deficiencies in tax education" that recently characterised the unauthorised (or perhaps more accurately, inept) activities of the National Revenue Administration bodies, which have been reported by the media, e.g. in terms of summoning ${ }^{58}$ the so-called "newlyweds" in connection with the activities carried out in relation to the owners of wedding halls, music bands or, more broadly, entrepreneurs running catering establishments and musical services for such events. It is an open secret that in this area of "business activity" there are notorious "pathologies" in terms of understatement of public receivables by entrepreneurs from the so-called wedding industry using various methods. The tax (revenue) authorities are

55 Cf. Judgment of Supreme Administrative Court of 24 November 2016, II FSK 1607/16, CBOSA.

56 Judgment of Voivodeship Administrative Court in Gliwice of 11 January 2017, III SA/Gl 2096/15, CBOSA; judgment of Voivodeship Administrative Court in Gliwice of 10 January 2017, III SA/Gl 2104/15, CBOSA. I. Nowak, Instytucja wyłq̨czenia organu podatkowego i jego pracowników jako gwarancja bezstronności przy podejmowaniu rozstrzygnięć podatkowych - uwagi krytyczne, „Toruński Rocznik Podatkowy” 2016/el, pp. 70-86.

57 However, provided that the latter is supplemented by postgraduate studies in tax law.

58 See I. Nowak, Wezwania w świetle pomocy prawnej pomiędzy organami administracji podatkowej na gruncie art. 157 i 157a Ordynacji podatkowej, „Kwartalnik Prawa Podatkowego" 2018, No 3, pp. 43-68; ibid. Dowód z przesłuchania strony w procedurze podatkowej - uwagi de lege lata i de lege ferenda, „Toruński Rocznik Podatkowy" 2018/el. 
of course empowered to prevent such situations. But what has failed? In my opinion, first of all the routine, but at the same time the lack of proper knowledge of procedural regulations by employees (officers) of the National Revenue Administration ${ }^{59}$. The result: 585 summons to so-called newlyweds ${ }^{60}$ under tax procedures have become ineffective ${ }^{61}$. On the other hand, the final nail in the coffin for the tax (revenue) authorities in counteracting the above irregularities was made - on an 'et tu, Brute, contra me' basis - by the Deputy Head of the National Revenue Administration in a letter dated 23 November 2018 addressed to the Directors of the Fiscal Administration Chambers, in which he indicated, inter alia, that “(...) in taking specific actions, e.g. in the area of monitoring the correctness of registration on fiscal cash registers, it will be primarily justified to apply behavioural measures towards a specific entity, and only as a result of their ineffectiveness will it be possible to take mandate actions. (...) At the same time, I would like to remind you that the head of an organisational unit is responsible for the correctness and manner of performance of tasks by subordinate employees"62. In conclusion, it is naivety, after such a letter, to think that the heads of organizational units of the National Rev-

59 See I. Nowak, Wyznaczenie stronie postępowania podatkowego terminu do przedstawienia dowodów będacych w jej posiadaniu na gruncie art. 189 Ordynacji podatkowej, „Przegląd Podatków Lokalnych i Finansów Samorządowych” 2019, No 5, pp. 18-23; ibid. Uznanie okoliczności faktycznych za udowodnione w świetle czynnego udziału podatnika w procedurze podatkowej, „Prawo Budżetowe Państwa i Samorządu” 2019, No 3, pp. 21-46.

60 The letter of the Minister of Finance of 13 December 2018, DNK7.054.14.2018, http://orka2.sejm.gov.pl/INT8.nsf/klucz/ATTB7FJX2/\%24FILE/i27758-o1.pdf, (access on-line: 28.10.2019.).

61 More broadly I. Nowak, Istota i znaczenie wezwań w postępowaniu podatkowym, „Przegląd Podatków Lokalnych i Finansów Samorządowych” 2019, No 7/8, pp. 2026/25-30; ibid. Dowód z zeznań świadka na gruncie jurysdykcyjnego postępowania podatkowego, „Prawo Budżetowe Państwa i Samorządu” 2019, No 1, pp. 129-165.

62 The letter of the Deputy Head of the National Revenue Administration dated 23 November 2018 (without number) addressed to the Directors of the Fiscal Administration Chambers; similarly in the letter of the Minister of Finance of 13 December 2018, No DNK7.054.14.2018, http://orka2.sejm.gov.pl/INT8.nsf/klucz/ATTB7FJX2/\%24FILE/ i27758-o1.pdf (access on-line: 28.10.2019). 
enue Administration will take effective action in the field of irregularities concerning the "wedding industry" 63 .

Empirical research shows that as of 30 June 2019, the total number of employees (officers) with higher education in the departments and offices of the Ministry of Finance's National Revenue Administration ${ }^{64}$ in the total number of staff members amounted to 51491 out of $62128^{65}$. Among employees (officers) of Fiscal Administration Chambers in Poland with higher education ${ }^{66}$ (see Chart $1-3$ ), economics is the most represented field of study (26.1\%) ${ }^{67}$. Administration comes second (17.5\%), while law as the only uniform 5-year course of study is represented at the level of $8.0 \%$ of people with higher education. The other fields of study are tax law and accounting (1.8\%), finance and accounting (1.4\%), and tax consultancy $(0.1 \%)^{68}$. This means that approx. $45.1 \%$ of employees (officers) of Fiscal Administration Chambers have a higher education - so to speak - "not matching" the assessment, collection, and enforcement of publiclaw levies. As far as post-graduate studies in tax law are concerned, which were completed by employees (officers) of Fiscal Administration Chambers, they account for only $2.4 \%$ of the total number of employees (in service) $^{69}$ - see Chart 3. Incidentally, it should be noted that the Minis-

63 Por. I. Nowak, Małżeństwo a zwiqzki partnerskie w świetle wybranych regulacji polskiego prawa podatkowego, „Kwartalnik Prawa Podatkowego” 2017, No 3, pp. 55-83.

64 The departments and offices of the National Revenue Administration of the Ministry of Finance employed 878 people (including 242 officers), 515 of whom have university degrees.

65 The letter of the Minister of Finance, Investment and Development of 1 October 2019, BMI1.0124.1063.2019.

66 The data do not take into account whether the studies are first or second degree. In accordance with the regulation of the Act of 20 July 2018 on Higher Education and Science (Dz.U. of 2018, poz. 1668 with subsequent amendments). The analogous remarks apply to all the majors adopted in the study - with the exception of law as a uniform 5-year master's degree course.

67 Data obtained by way of access to public information from the Directors of the Fiscal Administration Chambers in Poland, with the exception of completed courses of study by the employees (officers) of FAC in: Białystok and Poznań.

68 The figures do not include FAC staff (officers): Białystok, Bydgoszcz, Katowice, Olsztyn (excluding officers), Opole, Poznań and Rzeszów.

69 The figures do not include FAC staff (officers): Białystok, Katowice, Olsztyn, Poznań, Szczecin, Zielona Góra. 
try of Finance employs 2321 people $^{70}, 607$ of whom have an economic and 543 a legal education ${ }^{71}$. It should also be noted, in plus, that according to the National Treasury Information as of 12 September 2019, out of 971 employed persons, 901 have higher education, of whom 335 have higher economic education, 150 higher administrative education, and 126 higher legal education ${ }^{72}$.

In the light of the above considerations, it is also worth noting that both the Ministry of Finance and the National Revenue Administration do not have a centralised human resources system, which allows, among other things, to keep records of employees (officers) with regard to their education $^{73}$. Therefore, this type of inactivity which, after all, is of tremendous importance when it comes to establishing the right "personnel" of tax (revenue) authorities should be approached with great scepticism.

70 Data as of 22 July 2019 - the letter of the Minister of Finance of 21 August 2019, BDG7.054.14.2019, http://orka2.sejm.gov.pl/INT8.nsf/klucz/ATTBFBGZV/\%24FILE/ i32959-o1.pdf (access on-line: 30.10.2019).

71 The most popular courses of study among the employees of the Ministry of Finance, apart from the above, are: administration, finance, management - the letter of the Minister of Finance dated 30 August 2019, BDG7.054.15.2019, http://orka2.sejm.gov.pl/ INT8.nsf/klucz/ATTBFMHQP/\%24FILE/i33023-o1.pdf, (access on-line: 30.10.2019). Moreover, as of 17 July 2019, there were 99 graduates of the National School of Public Administration employed in the Ministry of Finance, and their average monthly basic salary was PLN 6581.92 gross - the letter of the Minister of Finance of 6 August 2019, BDG7.054.12.2019, http://orka2.sejm.gov.pl/INT8.nsf/klucz/ATTBEUHPB/ \%24FILE/i32594-o1.pdf, (access on-line: 30.10.2019).

72 The letter of the Director of National Treasury Information of 26 September 2019, 0110-KWP.0150.43.2019.3.

73 Each of the FAC in Poland has a separate HR and payroll program - the letter of the Minister of Finance, Investment and Development of 14 October 2019 r., BMI1.0124.1103.2019. 
Chart 1. Employees (officers) of Fiscal Administration Chambers in Poland by education (percentage share).

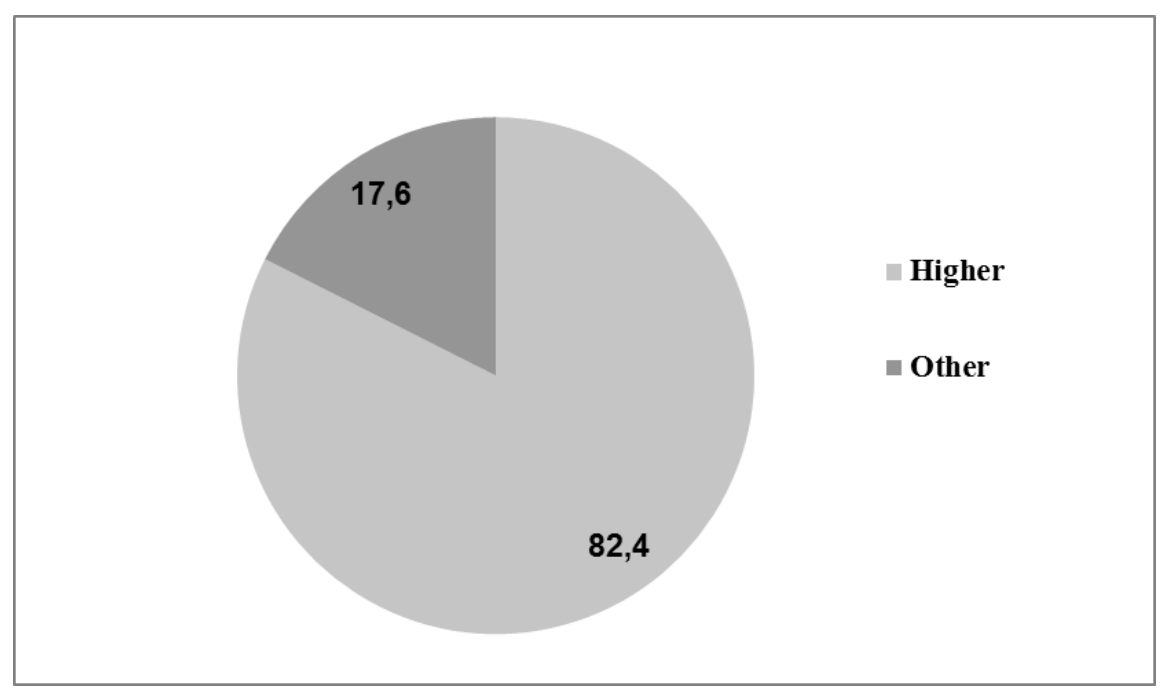

Chart 2. Employees (officers) of particular Fiscal Administration Chambers in Poland - in total and with higher education.

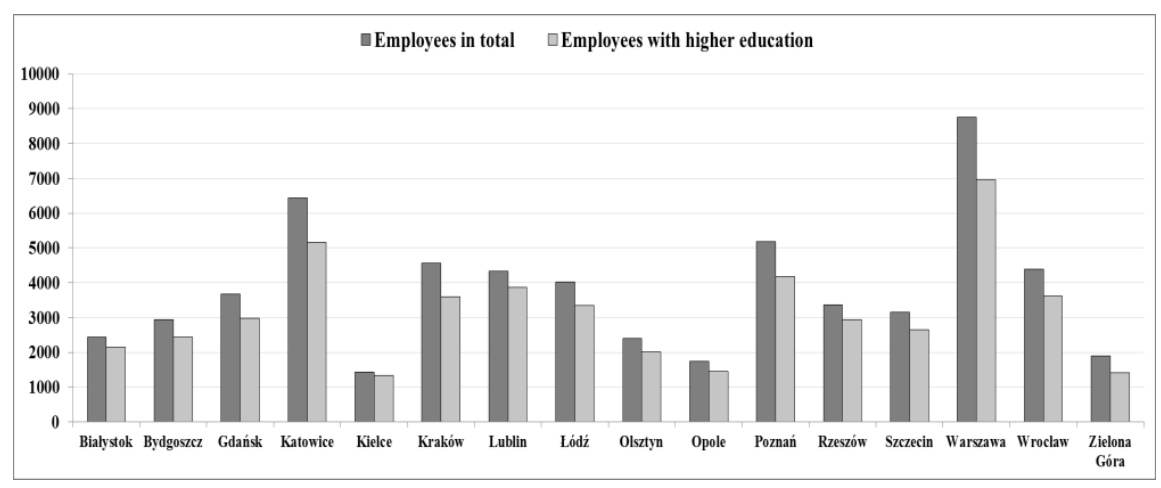

Prawo Budżetowe Państwa i Samorządu 2[8]/2020 
Chart 3. Main courses of study among employees (officers) of Fiscal Administration Chambers in Poland (percentage share).

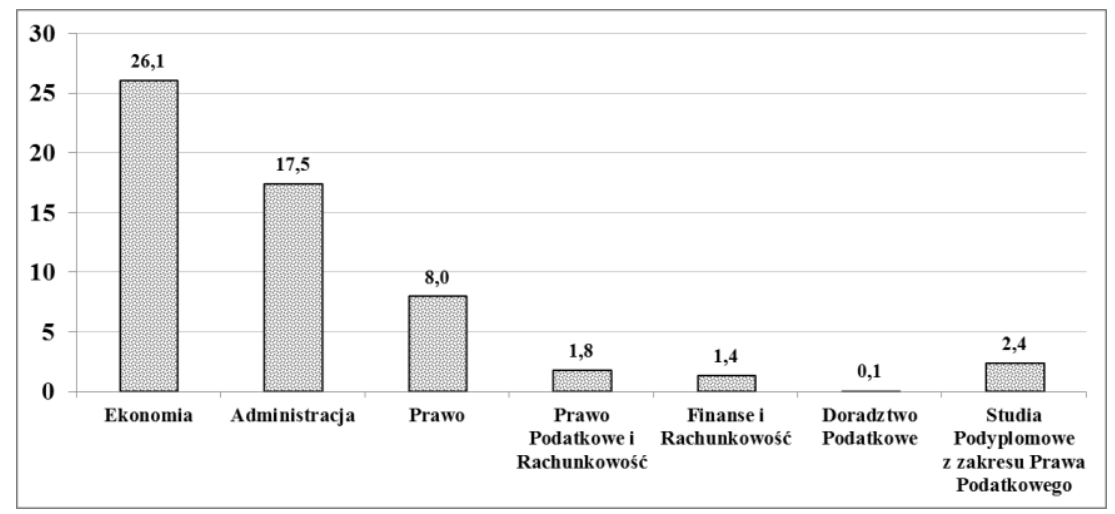

\section{Conclusion}

The establishment of the National Revenue Administration was the biggest of the reforms made in public administration over the last several decades $^{74}$, as it was mainly related to changes in the existing structures of tax administration, customs, and fiscal control services, but also in the division of tasks between these units ${ }^{75}$. The consolidation of the National Revenue Administration was carried out in two areas, i.e. within the

74 M. Banaś, Utworzenie Krajowej Administracji Skarbowej skutecznq reformq administracji skarbowej i celnej [in:] W. Federczyk (ed.), Stulecie polskiej administracji. Doświadczenia i perspektywy, Warszawa 2018, p. 23 et seq.; the letter of the Minister of Development and Finance of January 2017, DD3.054.3.2017.WAZ, http://orka2.sejm.gov.pl/INT8.nsf/klucz/658C47EE/\%24FILE/i08961-o1.pdf; the letter of the Minister of Development and Finance of 3 January 2017, AP3.054.2.2016, http://orka2.sejm.gov.pl/INT8.nsf/klucz/658C47EE/\%24FILE/i08533-o1.pdf; the letter of the Minister of Development and Finance of October 2016, RS2.054.10.2016, http://orka2.sejm.gov.pl/INT8.nsf/klucz/658C47ED/\%24FILE/i06486-o1.pdf; the letter of the Minister of Development and Finance of 31 October 2017, DKA8.054.14.2017, http://orka2.sejm.gov.pl/INT8.nsf/klucz/658C47F0/\%24FILE/ i16043-o1.pdf (access on-line: 29.10.2019).

75 I. Nowak, Efektywność zasady dwuinstancyjności postępowania podatkowego w świetle ustawy o administracji podatkowej [in:] Ł.J. Pikuła, H. Kaczmarczyk (ed.), Granice efektywności prawa. Sposoby osiqgania efektywności w prawie, Toruń 2016, pp. 59-76. 
framework of the so-called merger of the departments in question at the central level in the Ministry of Finance, and the entity merger at the regional and local level of tax chambers and offices, customs chambers and offices, tax control offices ${ }^{76}$ - into fiscal administration chambers and customs and tax offices ${ }^{77}$.

As of the date of entry into force of the Act on the National Revenue Administration, all employees and officers working or serving in the tax administration, customs, or tax control offices became employees or officers of the National Revenue Administration ${ }^{78}$. However, an important

76 As of 30 April 2016, in the structures of the administration of public levies, the employment level (including, among others, fixed-term contracts and substitution contracts) was 67758, of which in:

a) Ministry of Finance - 2221 people;

b) fiscal chambers and offices -45098 people;

c) customs chambers and offices -14987 people;

d) fiscal inspection offices - 5452 people - acc. to the letter of the Minister of Finance of 9 June 2016, BDG7.054.3.2016, http://orka2.sejm.gov.pl/INT8.nsf/klucz/323A0944/\%24FILE/i03269-o1.pdf; see also the letter of the Minister of Development and Finance of 30 November 2016, RS1.054.6.2016, http://orka2.sejm.gov.pl/INT8.nsf/klucz/658C47ED/\%24FILE/i07499-o1.pdf; the letter of the Minister of Development and Finance of April 2017, RS6.054.9.2017, http://orka2.sejm.gov.pl/INT8.nsf/klucz/658C47EF/\%24FILE/i11425-o1.pdf; the letter of the Minister of Development and Finance of 19 April 2017, RS6.054.10.2017, http://orka2.sejm.gov.pl/INT8.nsf/klucz/658C47EF/\%24FILE/i11376-o1.pdf; the letter of the Minister of Development and Finance of 27 April 2017, BDG7.054.2.2017, http://orka2.sejm.gov.pl/INT8.nsf/klucz/658C47EF/\%24FILE/i11696-o1.pdf; the letter of the Minister of Development and Finance of 27 July 2017, DLK2.054.15.2017, http://orka2.sejm.gov.pl/INT8.nsf/klucz/658C47F0/\%24FILE/i13839-o1.pdf; the letter of the Minister of Development and Finance of 8 August 2017, DLK2.054.22.2017, http://orka2.sejm.gov.pl/INT8.nsf/klucz/658C47F0/\%24FILE/i14265-o1.pdf (access on-line: 30.10.2019).

77 The letter of the Minister of Development and Finance of 31 October 2017, DKA8.054.14.2017, http://orka2.sejm.gov.pl/INT8.nsf/klucz/658C47F0/\%24FILE/i16043-o1.pdf (access on-line: 28.10.2019).

78 See e.g. the letter of the Minister of Development and Finance of April 2017, AP2.054.3.2017, 
shortcoming related to the establishment of the National Revenue Administration is the fact that the law linking the tax administration, customs and fiscal control entered into force too prematurely, without a sufficient assessment of its effects and with the "great turmoil" regarding the employment of all employees (not only customs officers ${ }^{79}$ ). At the same time, the number of persons employed or serving in respective institutions who did not receive job/service offers in connection with the establishment of the National Revenue Administration totalled $2664^{80}$. More controversy is stirred up by the number of customs officers - 3839 - who, as a result of the reorganization of the existing structures, have lost their status, becoming so-called "civil servants" Union Celnicy PL) points out ${ }^{82}$, "many officers and employees who are entitled to a pension or who are approaching retirement age have been

http://orka2.sejm.gov.pl/INT8.nsf/klucz/658C47EF/\%24FILE/i11106-o1.pdf （access on-line: 28.10.2019); M. Laszuk, Status prawny Służby Celno-Skarbowej, „Przegląd Prawa Publicznego" 2018, No 6, p. 129 et seq.; W. Byrzykowski, A. Zdunek, Ustawa o Krajowej Administracji Skarbowej - organy, zadania oraz forma ich realizacji, „Przegląd Podatkowy” 2017, No 3, p. 47 et seq.

79 See https://celnicy.pl/threads/kontroler-z-konspiry.16183/ and S. Sękowski, Kontroler z konspiry, „Do Reczy” 33/2019.

80 According to the letter of the Minister of Finance of June 2018, DLK1.054.8.2018, http://orka2.sejm.gov.pl/INT8.nsf/klucz/658C47F3/\%24FILE/i22225-o1.pdf (access on-line: 28.10.2019).

81 Ibidem. As M. Rząsa rightly stressed in his interpellation with the Minister of Finance: "on the example of the IAS in Rzeszów, it can be said straightforwardly that the implemented civilianization did not make any sense, as two recruitments for over 210 officers were announced shortly afterwards. Additionally, we should report that the recruitments were unsuccessful due to the small number of suitable candidates. Needless to say, the process of training an officer is long and expensive, and here, the trained and experienced officers were simply given up on" - interpellation No 33509 to the Minister of Finance in the matter of the human resources policy within the NRA, which is incomprehensible and inconsistent with the Supreme Administrative Court's line of rulings, resulting in, among other things, illogical resignation from FAC Rzeszów officers leading to weakening of the eastern border of Poland and, at the same time, the European Union, http://www.sejm.gov.pl/sejm8.nsf/InterpelacjaTresc.xsp?key=BFVDYR\&view=6.

82 It is worthwhile to read the recording of the hearing of S. Siwy before the Sejm's Investigation Committee to examine the correctness and legality of actions and the occurrence of negligence and omissions of public bodies and institutions in the area of ensuring revenue of the State Treasury from value added tax and excise tax in the period from December 2007 to November 2015 - https://www.sejm.gov.pl/Sejm8.nsf/Pos KomZrealizowane.xsp?komisja=SKVAT\#79 (access on-line: 28.10.2019). 
subject to illegal coercion consisting in submitting applications for dismissal from service. Refusal to make such a statement meant that no service/work proposal was made. In our view, this was done in order to fictitiously reduce the scale of dismissals, as well as to avoid the lawsuits for age discrimination (...) As a result of the implementation of the law introducing NRA, many people were demotivated in an environment where pay rises were announced, people with high qualifications and experience and many years of experience were demotivated, and practically equated with newly recruited staff"83. Nota bene, Mr. S. Siwy himself was not offered employment in the National Revenue Administration (sic!). Is it possible that the President of the Customs Union PL is not one of the officers "who meet the highest standards - both in terms of substantive knowledge, competence and standing" ${ }^{84}$, to continue to serve in a modern, professional, and trustworthy tax (revenue) administration? ${ }^{85}$ As a result, it is difficult to assume a priori that the Directors of Fiscal Administration Chambers when hiring employees (officers) were guided solely by the competence of the applicants ${ }^{86}$. Moreover, it cannot be ignored that in the period from 1 March 2017 to 31 March 2019, the dismissed employees (officers) and those whose remuneration was reduced, brought against the Directors of Fiscal Administration Chambers 1161 suits to voivodeship administrative courts and common courts ${ }^{87}$.

In the context of the above, it seems that the intention of the legislator reforming the administration of public levies did not fully materialize. And the assurances of the then Head of the National Revenue Administra-

83 The letter of S. Siwy (Chairman of the Customs Union Celnicy PL) of 2 June 2017 addressed to officers, civil servants and employees of the National Revenue Administration, http://solid.home.pl/kas/celnicypl.pdf.

84 Cf. the letter of the Minister of Development and Finance dated 8 August 2017, DLK2.054.22.2017, http://orka2.sejm.gov.pl/INT8.nsf/klucz/658C47F0/\%24FILE/ i14265-o1.pdf (access on-line: 30.10.2019).

85 Ibidem.

86 Cf. the letter of the Minister of Finance dated 19 December 2018, BDG7.054.24.2018, http://orka2.sejm.gov.pl/INT8.nsf/klucz/ATTB7REBW/\%24FILE/i27825-o1.pdf (access on-line: 28.10.2019).

87 According to the letter of the Minister of Finance of April 2019, DLK11.054.1.2019, http://orka2.sejm.gov.pl/INT8.nsf/klucz/ATTBBDDBQ/\%24FILE/i30349-o1.pdf (access on-line: 28.10.2019). 
tion saying that "one of the most important factors determining the success of the tax administration reform is the stabilization of the professional and financial situation of NRA's staff" ${ }^{\prime 8}$ cannot be fully accepted. It is worth noting here J. Cichon's observation that the reform of the revenue administration was used for numerous "layoffs and personnel purges", and that personnel castling "introduced great chaos in offices and losses to the state budget. (...) All of these activities increase the frustration of employees and officers, resulting in people with great experience and knowledge leaving their jobs or service. Lack of stability and protection against unjustified and unfair dismissal, non-compliance with statutory criteria, lack of job offers, civilianization as a process unknown in civilized states of law, significant reductions in salaries and positions, relocation to other places, transfer to cells that do not match the previous experience, degradation of knowledge and skills, lowering the professionalism of management, nepotism, cronyism, and lack of criteria for recruitment to managerial positions cause a huge decrease in motivation to work or serve" ${ }^{89}$.

In recent years, there has been a very high turnover in the tax (revenue) authorities, which makes their "activity" largely dependent on new, inexperienced employees, whose education is far from being translated into the tasks realized ${ }^{90}$. At the same time, it should be noted that the proper functioning of the tax (revenue) administration, and in particular its effectiveness, depends, as a rule, on the proper substantive preparation of its employees (officers), duly supported, of course, by an appropriate human resources policy, including motivation policy ${ }^{91}$. Moreover, due to the complexity of tax law and the "growing finesse of economic and financial

88 Pursuant to parliamentary interpellation No 30349 J. Cichoń to the Minister of Finance on the reform of revenue administration,

http://www.sejm.gov.pl/Sejm8.nsf/InterpelacjaTresc.xsp?key=BAPKA7 (access on-line: 29.10.2019).

89 Ibidem.

90 R. Kosińska, E. Ruśkowski, P. Woltanowski, Efektywność..., pp. 17-27.

91 B. Brzeziński, Współczesne problemy organizacji i działania administracji podatkowej na świecie, „Kwartalnik Prawa Podatkowego” 2002, No 2, p. 19; M. Kaliński, Rozwój zasobów ludzkich w administracji podatkowej, „Zarządzanie Zasobami Ludzkimi” 2011, No 5, pp. 49-67. 
operations aimed at avoiding taxation"92 inside the structure of the tax (revenue) apparatus, professional and specialized personnel become necessary $^{93}$. And here, as empirical material shows, we still have a long way to go. Unfortunately, the National Revenue Administration is very far from the standards that the Minister of Finance (and, of course, every taxpayer) would wish for, namely that all employees and officers should not only have extensive knowledge and experience, but also a personal culture and guarantee high ethical standards, as only on these grounds is it possible to build citizens' confidence in the new organization ${ }^{94}$. Therefore, we are all - employees and officers as well as taxpayers - awaiting the investments in the staff of the National Revenue Administration announced by the Minister of Finance, introducing, among others, motivational tools for salary regulation ${ }^{95}$.

Summarizing the above considerations, one should also notice the positive aspects of the "modernization" of the National Revenue Administration, including, inter alia, salary increases in the years 2020-2022 ${ }^{96}$. Moreover, it is worth noting that in 2019 rises were paid out to employees in the amount of PLN 605 gross per month, and PLN 606 gross per month for officers of the Customs and Fiscal Service, with these amounts also

92 B. Brzeziński, W. Nykiel, Stan..., p. 75.

93 B. Brzeziński, Prawo podatkowe. Zagadnienia teorii i praktyki, Toruń 2017, p. 183 et seq.

94 The letter of the Minister of Development and Finance dated 8 August 2017, DLK2.054.22.2017,

http://orka2.sejm.gov.pl/INT8.nsf/klucz/658C47F0/\%24FILE/i14265-o1.pdf; The letter of the Minister of Finance dated for March 2018, http://orka2.sejm.gov.pl/INT8.nsf/ klucz/658C47F2/\%24FILE/i19750-o1.pdf (access on-line: 30.10.2019).

95 M. Banaś, Projekt modernizacji gotowy, „Dziennik Gazeta Prawna”, 26-28 April 2019, No 82 (4984), p. E4; see also the resolution of the Council of Ministers No 44/2019 of 28 May 2019 on the establishment of the multiannual programme "Modernisation of the National Revenue Administration in the years 2020-2022" and its annexes, https://www.gov.pl/web/kas/modernizacja-kas (access on-line: 30.10.2019).

96 For example, in 2020, an additional annual remuneration for employees and an annual award for officers in the amount of 50 PLN/49 PLN per month gross is to be paid - the letter of the Minister of Finance of 14 March 2019, DLK6.054.2.2019.2, http://orka2.sejm.gov.pl/INT8.nsf/klucz/ATTBAEEF4/\%24FILE/i28585-o2.pdf （access on-line: 30.10 .2019 r.). 
including a write-off for the funds of rewards for professional achievements (3\% of remuneration for planned personnel funds) ${ }^{97}$.

\section{Bibliography:}

Banaszak B., Konstytucja Rzeczypospolitej Polskiej. Komentarz 2012, Legalis/el.

Banaś M., Utworzenie Krajowej Administracji Skarbowej skutecznq reformq administracji skarbowej i celnej [in:] W. Federczyk (ed.), Stulecie polskiej administracji. Doświadczenia i perspektywy, KSAP, Warszawa 2018.

Banaś M., Projekt modernizacji gotowy, „Dziennik Gazeta Prawna”, 26-28 April 2019, No 82 (4984), p. E4.

Bielecki L., Ustrojowe prawo administracyjne (podatkowe) dotyczqce Krajowej Administracji Skarbowej jako przykład wpływu ideologii politycznej na kształt prawa, „Przegląd Prawa Publicznego” 2017, No 7-8, pp. 44-52.

Bielecki L., Gorgol A. (eds), Ustawa o Krajowej Administracji Skarbowej. Komentarz, C.H. Beck, Warszawa 2018.

Brzeziński B., Współczesne problemy organizacji i działania administracji podatkowej na świecie, „Kwartalnik Prawa Podatkowego” 2002, No 2, pp. 9-24.

Brzeziński B., Nykiel W., Legislacja podatkowa [in:] B. Brzeziński (ed.), Prawo podatkowe. Teoria. Instytucje. Funkcjonowanie, TNOiK, Toruń 2009.

Brzeziński B., Nykiel W., Stan prawa podatkowego w Polsce. Raport 2010, „Kwartalnik Prawa Podatkowego” 2011, No 1 pp. 61-83.

Brzeziński B., Prawo podatkowe. Zagadnienia teorii i praktyki, TNOiK, Toruń 2017.

Byrzykowski W., Zdunek A., Ustawa o Krajowej Administracji Skarbowej organy, zadania oraz forma ich realizacji, „Przegląd Podatkowy” 2017, No 3, pp. 47-52.

Dębowska-Romanowska T., Zdanie odrębne do wyroku TK z dnia 6 marca 2002 r., P. 7/2000, Legalis/el.

Gomułowicz A., Moralność podatkowa - uwarunkowania i zasadnicze dylematy [in:] A. Gomułowicz, J. Małecki (ed.), Ex iniuria non oritur ius. Księga pamiq̨tkowa ku czci Profesora Wojciecha Łq̨czkowskiego, UAM, Poznań 2003.

97 The raises will be paid out by the end of the third quarter of 2019, with a compensation from 1 January 2019 - the letter of the Minister of Finance of December 2018, DLK6.054.5.2018,

http://orka2.sejm.gov.pl/INT8.nsf/klucz/ATTB7BJK5/\%24FILE/i27640-o1.pdf (access on-line: 28.10.2019). 
Laszuk M., Status prawny Służby Celno-Skarbowej, „Przegląd Prawa Publicznego” 2018, No 6, pp. 129-138.

Leśniak G., 30 lat urzędów skarbowych w Polsce: Przydałby się szef administracji podatkowej, https://podatki.gazetaprawna.pl/wywiady/677504,30-laturzedow-skarbowych-w-polsce-przydalby-sie-szef-administracjipodatkowej.html (access on-line: 25.10.2019).

Leśniak G., Administracja skarbowa w rękach osób pełniqcych obowiq̨zki. To próba obchodzenia prawa, https://podatki.gazetaprawna.pl/artykuly/680803,administracja-skarbowa-wrekach-osob-pelniacych-obowiazki-to-proba-obchodzenia-prawa.html (access on-line: 20.10.2019).

Kaliński M., Rozwój zasobów ludzkich w administracji podatkowej, „Zarządzanie Zasobami Ludzkimi” 2011, No 5, pp. 49-67.

Kosińska R., Ruśkowski E., Woltanowski P., Efektywność służb podatkowych w okresie ich reformowania - wybrane zagadnienia, „Finanse, Rynki Finansowe, Ubezpieczenia” 2016, No 6, pp. 17-27.

Kulicki J., Koncepcja Krajowej Administracji Skarbowej w świetle problemów administracji danin publicznych w Polsce, „Analizy i Studia” 2016, No 2, pp. 10-39.

Kulicki J., Administracja danin publicznych w Polsce, WS, Warszawa 2014.

Mariański A., Rozstrzyganie wq̨tpliwości na korzyść podatnika. Zasada prawa podatkowego, Wolters Kluwer, Warszawa 2009.

Mastalski R., Wprowadzenie do prawa podatkowego, C.H. Beck, Warszawa 1995.

Melezini A., Teszner K. (eds), Krajowa Administracja Skarbowa. Komentarz, Wolters Kluwer, Warszawa 2018.

Nowak I., Instytucja wyłq̨czenia organu podatkowego i jego pracowników jako gwarancja bezstronności przy podejmowaniu rozstrzygnięć podatkowych uwagi krytyczne, „Toruński Rocznik Podatkowy” 2016/el, pp. 70-86.

Nowak I., Efektywność zasady dwuinstancyjności postępowania podatkowego w świetle ustawy o administracji podatkowej [in:] Ł.J. Pikuła, H . Kaczmarczyk (eds), Granice efektywności prawa. Sposoby osiagania efektywności w prawie, AM, Toruń 2016.

Nowak I., Ciężar dowodzenia w postępowaniu podatkowym - podstawowe problemy [in:] B. Kucia-Guściora, M. Münnich, A. Zdunek, R. Zieliński (ed.), Stanowienie i stosowanie prawa podatkowego w Polsce. Ocena i kierunki zmian, KUL, Lublin 2016. 
Nowak I., Koszty uzyskania przychodów z praw autorskich przysługujq̨ce nauczycielom akademickim, „Toruński Rocznik Podatkowy” 2017/el, pp. 165-197.

Nowak I., Małżeństwo a zwiq̨zki partnerskie w świetle wybranych regulacji polskiego prawa podatkowego, „Kwartalnik Prawa Podatkowego” 2017, No 3, pp. 55-83.

Nowak I., Upoważnienie pracownika do załatwiania spraw w imieniu samorzqdowego organu podatkowego, „Przegląd Podatków Lokalnych i Finansów Samorządowych” 2017, No 10, pp. 19-27.

Nowak I., Terminowość załatwiania spraw przed samorzq̨owymi organami podatkowymi, „Przegląd Podatków Lokalnych i Finansów Samorządowych” 2017, No 11/12, pp. 18-26/21-28.

Nowak I., Dowód z przesłuchania strony w procedurze podatkowej - uwagi de lege lata i de lege ferenda, „Toruński Rocznik Podatkowy” 2018/el.

Nowak I., Wezwania w świetle pomocy prawnej pomiędzy organami administracji podatkowej na gruncie art. 157 i 157a Ordynacji podatkowej, „Kwartalnik Prawa Podatkowego" 2018, No 3, pp. 43-68.

Nowak I., Dominiak M., Krajowa Administracja Skarbowa a uszczelnianie systemu podatkowego - spostrzeżenia po dwóch latach funkcjonowania [in:] P. Łabuz, I. Malinowska, M. Michalski (ed.), Przestępczość gospodarczoekonomiczna - przeciwdziałanie i zwalczanie, Difin, Warszawa 2020.

Nowak I., Dowód z zeznań świadka na gruncie jurysdykcyjnego postępowania podatkowego, „Prawo Budżetowe Państwa i Samorządu” 2019, No 1, pp. 129-165.

Nowak I., Uznanie okoliczności faktycznych za udowodnione w świetle czynnego udziału podatnika w procedurze podatkowej, „Prawo Budżetowe Państwa i Samorządu” 2019, No 3, pp. 21-46.

Nowak I., Wyznaczenie stronie postępowania podatkowego terminu do przedstawienia dowodów będqcych w jej posiadaniu na gruncie art. 189 Ordynacji podatkowej, „Przegląd Podatków Lokalnych i Finansów Samorządowych” 2019, No 5, pp. 18-23.

Nowak I., Istota i znaczenie wezwań w postępowaniu podatkowym, „Przegląd Podatków Lokalnych i Finansów Samorządowych” 2019, No 7/8, pp. 2026/25-30.

Różycki K., Bielska-Brodziak A., Właściwość rzeczowa organów podatkowych, Lex/el.

Skrzydło W., Konstytucja Rzeczypospolitej Polskiej. Komentarz 2013, Lex/el. 
Suchodolska M., KAS, czyli każda anomalia skasowana, „Dziennik Gazeta Prawna” of 29 April - 5 May 2019, no. 83/84/85 (4985/4986/4987), year 25, p. 18.

Teszner K., Administracja podatkowa i kontrola skarbowa w Polsce 2012, Lex/el.

Teszner K., Wincenciak M., Pietrasz P., Nowe tendencje w procedurach kontrolnych na przykładzie kontroli celno-skarbowej [in:] Jagielski J., Wierzbowski M. (eds), Prawo administracyjne dziś i jutro 2018, Lex/el.

Teszner K., Uprawnienia radcy skarbowego $w$ zakresie załatwiania spraw podatkowych, „Procedury Administracyjne i Podatkowe” 2018, No 2, pp. 17-24.

Teszner K., Komentarz do art. 13 o.p. [in:] Etel L. (ed.), Ordynacja podatkowa. Komentarz 2019, Lex/el.

Wojciechowski T., Urzędnicy skarbowi odchodzq z urzędów. Zamiast karać, pomagajq podatnikom, https://podatki.gazetaprawna.pl/artykuly/663749,urzednicyskarbowi-odchodza-z-urzedow-zamiast-karac-pomagaja-podatnikom.html (access on-line: 24.10.2019). 